\title{
Compaction and consolidation behaviour of untreated and treated waste of Indian red mud
}

1 Narala Gangadhara Reddy MTech

Research Scholar, School of Infrastructure, Indian Institute of Technology Bhubaneswar, Bhubaneswar, India
2 Bendadi Hanumantha Rao PhD

Assistant Professor, School of Infrastructure, Indian Institute of Technology Bhubaneswar, Bhubaneswar, India (corresponding author: bhrao@iitbbs.ac.in)
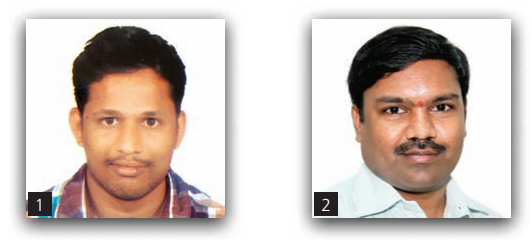

This study deals with the evaluation of the compaction and consolidation characteristics of untreated as well as hydrochloric acid $(\mathrm{HCl})$ - and sodium chloride $(\mathrm{NaCl})$-treated red mud wastes. A series of standard and modified Proctor compaction and one-dimensional consolidation tests were conducted for the study purpose. Sodium chloride solutions of 1.71 and $3.42 \mathrm{M}$ and hydrochloric acid solutions with $\mathrm{pH}$ of 1, 1.5, 2, 3 and 4 are selected to treat the waste. Results show that standard Proctor compaction tests yield inconsistent and low dry unit weight values with relatively high optimum water content. On the other hand, modified Proctor compaction test produced consistent dry unit weight values with low optimum water content. There is only a marginal improvement in dry unit weight and compression properties of hydrochloric acid- and sodium chloride-treated samples; however, the treatment proved effective in reducing $\mathrm{pH}$ of the waste. It has been noticed that the compressibility of both untreated and treated samples is appreciably low. Results elucidate that parameters such as the size of the particles and their shape, chemical and mineralogical compositions and surface charge properties can influence the compaction and compressibility characteristics of the waste. Overall, the study demonstrates that the red mud waste could be a potential resource material for geotechnical engineering applications.

\section{Notation}

$A_{\mathrm{c}} \quad$ activity of soil

$c_{\mathrm{c}} \quad$ compression index

$d$ diameter of a particle: $\mathrm{mm}$

e void ratio: $\mathrm{m}^{3} / \mathrm{m}^{3}$

$e_{0} \quad$ initial void ratio: $\mathrm{m}^{3} / \mathrm{m}^{3}$

$G_{\mathrm{s}} \quad$ specific gravity

$m_{\mathrm{v}} \quad$ coefficient of volume change: $\mathrm{m}^{2} / \mathrm{kN}$

$p \quad$ applied pressure: $\mathrm{kPa}$

$w \quad$ water content: \%

$w_{\mathrm{L}} \quad$ liquid limit: \%

$w_{\text {opt }} \quad$ optimum water content

$w_{\mathrm{P}} \quad$ plastic limit: \%

$w_{\mathrm{PI}} \quad$ plasticity index: $\%$

$\gamma_{\mathrm{d}} \quad$ dry unit weight: $\mathrm{kN} / \mathrm{m}^{3}$

$\gamma_{\text {dmax }}$ maximum dry unit weight: $\mathrm{kN} / \mathrm{m}^{3}$

$\Delta e \quad$ net change in void ratio

\section{Introduction}

Red mud waste (RMW) is a solid residue generated during the extraction of alumina from bauxite ore by Bayer's process. A substantial amount of hot caustic soda $(\mathrm{NaOH})$ is added during the process of extraction of alumina, resulting in the generation of residue possessing a very high alkalinity, with $\mathrm{pH}$ ranging from $10 \cdot 5$ to 13 . The waste largely contains silt and clay-sized particles, but does not contain either quartz or claylike minerals, which are typically present in sandy or clayey soils (Somogyi and Gray, 1977). Interestingly, in the absence of either quartz or clay minerals, it is reported that the waste exhibits a compression and plastic behaviour similar to that of clayey soils and a frictional behaviour the same as that of sandy soils, and many of its geotechnical properties match with those of clayey tailings (Gray and Somogyi, 1974; Newson et al., 2006; Parekh and Goldberger, 1976). These attributes suit the waste for selection as a resource material in geotechnical applications such as embankments, pavements, roads, structural fills and other earthen structures.

As such, studies investigating the effect of alkalinity $(\mathrm{pH}>11)$ on dry unit weight against water content relationship and compressibility properties of RMW are almost nil. Dry unit weight and water content correlate well with the engineering properties and thus become convenient controlling parameters (Kaniraj and Havanagi, 2001). Since the objective of compaction is to improve 
the engineering behaviour of any soil/waste, it is important to determine the compaction and consolidation properties of a filling material. Settlement in a waste/soil is the reaction to an applied stress or loading, which ensues due to the construction of a building or any structure that ultimately leads to strain on the material. As such, compaction and consolidation properties largely control the load-bearing and deformation characteristics of a material (Leroueil, 1988). Hence, establishment of these properties becomes vital in all practical perspectives. Moreover, these properties can become a basis for ascertaining the suitability of a material to be selected as resource material for constructing an earthen structure (Winterkorn and Fang, 1991).

The utilisation of RMW is almost insignificant compared with its generation, and very limited research is available in the literature. Parekh and Goldberger (1976) and Rout et al. (2013) evaluated the physical and chemical properties of RMW to explore its usefulness in embankments, tailing dams and other civil engineering applications. Similarly, Somogyi and Gray (1977) and Nikraz et al. (2007) determined the consolidation characteristics of red mud for understanding its settlement behaviour and other geotechnical properties. Ekrem (2006) examined the potential use of red mud for the stabilisation of expansive soils which would be used in clay lining systems. Kehagia (2008) utilised red mud for the construction of a road embankment on a pilot project scale. Investigations on the use of red mud blended with other waste materials such as fly ash for making of heavy clay products have been carried out by Hajela et al. (1989). Giannopoulou et al. (2009) attempted the geopolymerisation of RMW with slag to develop polymeric materials with superior mechanical and physical properties.

Overall, the studies reveal that the use of RMW has been very minimal in geotechnical applications (Power et al., 2011; Rai et al., 2012). One of the reasons for the low-volume utilisation of this waste may be due to high alkalinity levels, with $\mathrm{pH}$ above 11, and likely leaching of harmful elements under extreme alkaline conditions that may contaminate soil and groundwater, apart from posing a threat to the surrounding geoenvironment (Borra et al., 2015; Power et al., 2011). Moreover, engineering behaviour including compaction, compressibility and strength aspects, which may be affected with time due to the high $\mathrm{pH}$ levels of RMW, is poorly understood. Apart from this, efforts are also lacking in establishing the geotechnical and geochemical properties of this waste in a comprehensive way. However, a few studies that have been carried out so far on RMW suggest that treating the waste with suitable additives such as seawater, acid and carbon dioxide $\left(\mathrm{CO}_{2}\right)$ (Khaitan et al., 2009a, 2010; Rai et al., 2012) is mandatory in order to reduce the high $\mathrm{pH}$. Moreover, many of the code specifications avoid using alkaline waste/soil with $\mathrm{pH}$ above 8.5 (IRC SP 20-2001 (IRC, 2001a), IRC SP 58-2001 (IRC, 2001b)).

This paper focuses on evaluation of the compaction and consolidation characteristics of RMW, in a comprehensive way, before and after it was treated with hydrochloric acid $(\mathrm{HCl})$ and sodium chloride $(\mathrm{NaCl})$ solutions. These two chemicals have been selected based on findings reported in the literature (Hanahan et al., 2004; Khaitan et al., 2009b; Rai et al., 2012). It can also be noted here that the mixing of acid (hydrochloric acid) and base (RMW) is a well-recognised method of neutralisation to bring down $\mathrm{pH}$ levels. A series of compaction (both standard Proctor (SP) and modified Proctor (MP)) and one-dimensional consolidation tests have been performed on the untreated as well as treated samples. The results obtained are critically evaluated by comparing them with those of code specifications, different waste types and chemically altered soils. The study bears a practical significance in terms of promoting the utilisation of waste in various geotechnical engineering applications as well as in ascertaining its suitability in these applications.

\section{Materials and testing methods}

The RMW used in this study has been collected from the disposal pond of National Aluminium Company Limited, Damanjodi, Koraput, Odisha, India. The disposal site is located in the eastern part of India. All samples have been collected in a wet state and oven-dried prior to testing. The specific gravity of a sample has been determined by the pycnometer bottle method in accordance with the ASTM D 854 standard (ASTM, 2014a). For accuracy, an average value obtained from the tests conducted in triplicate is considered representative, as listed in Table 1. The consistency limits, grain size distribution and $\mathrm{pH}$ of red mud are determined in accordance with the ASTM D 4318-10 (ASTM, 2010a), D 4943-08 (ASTM, 2008), D 422-63 (ASTM, 2010b), D 1140-14 (ASTM, 2014b) and D 4972-13 (ASTM, 2013) standards, respectively. RMW is classified as per the Unified Soil Classification System (USCS) (ASTM D 2487-11 (ASTM, 2011a)) by using percentage fractions from gradational characteristics and consistency limits.

\section{Preparation of chemical solutions}

Hydrochloric acid solutions of different $\mathrm{pH}$ levels - specifically, 1 , $1 \cdot 5,2,3$ and 4 - were prepared by diluting $11 \cdot 65 \mathrm{M}$ concentrated hydrochloric acid solution in the desired quantity of distilled water. In addition, sodium chloride solution was prepared by dissolving the desired amount of salt in distilled water. In the present study, sodium chloride solutions were prepared corresponding to 1.71 and $3 \cdot 42 \mathrm{M}$.

\section{Compaction and consolidation tests}

SP and MP tests have been carried out in accordance with the ASTM D 698-07 (ASTM, 2007) and ASTM D 1557-12 (ASTM, 2012) standards. In the present study, a series of SP and MP tests have been conducted on untreated as well as sodium chloride- and hydrochloric acid-treated RMW samples. In addition, compaction curves were also established as a function of compactive effort. Different compaction efforts were achieved by varying the number of blows (i.e. 12, 15, 18, 22, 25, 28, 33, 45 and 56) following the study of Sridharan and Sivapullaiah (2005).

One-dimensional consolidation tests have been performed using an oedometer apparatus following the procedure of the ASTM D 
Table 1. Physical properties of untreated RMW, fly ash and natural soils

\begin{tabular}{|c|c|c|c|c|}
\hline Serial number & Property & Red mud & Fly $a h^{a}$ & Natural soils ${ }^{b}$ \\
\hline $\begin{array}{l}1 \\
2\end{array}$ & $\begin{array}{c}\text { Specific gravity } G_{s} \\
\text { Consistency limits: \% }\end{array}$ & $3 \cdot 05$ & $1 \cdot 90-2 \cdot 55$ & $2 \cdot 60-2 \cdot 80$ \\
\hline \multirow{8}{*}{3} & $w_{L}$ & 41 & - & $25-50$ \\
\hline & $W_{p}$ & 36 & - & $10-20$ \\
\hline & $W_{\mathrm{PI}}$ & 5 & Non-plastic & $15-30$ \\
\hline & Percentage fraction & & & \\
\hline & Gravel & 0 & $0-10$ & $<10$ \\
\hline & Sand & $2-5$ & 7-90 & $30-50$ \\
\hline & Silt & $68-76$ & $8-85$ & $20-35$ \\
\hline & Clay & $22-27$ & $1-10$ & $50-70$ \\
\hline 4 & $\mathrm{pH}$ & $10 \cdot 7-11 \cdot 5$ & - & $<9$ \\
\hline 5 & Activity $A_{c}$ & $0.19-0.22$ & - & $0.2-0.7$ \\
\hline 6 & Classification & $\mathrm{ML}$ & $M L$ & $\mathrm{CL}, \mathrm{Cl}, \mathrm{MI}$ \\
\hline
\end{tabular}

a IRC SP 58-2001 (IRC, 2001b)

${ }^{b}$ IS 1498-1970 (BIS, 2007) and IS 12169-1987 (BIS, 1997)

2435-11 standard (ASTM, 2011b), and tests have been conducted on untreated and hydrochloric acid- and sodium chloride-treated samples. Effective stresses from 10 to $760 \mathrm{kPa}$ were applied during the loading condition. and upon reaching the maximum loading condition, unloading was done by removing the load in steps twice that of applied load. RMW samples of 1:1 ratio by weight (i.e. $1 \mathrm{~g}$ of red mud to $1 \mathrm{ml}$ of chemical solution) have been considered for conducting tests.

\section{Mineralogical and morphological characteristics}

The mineralogical characteristics of red mud samples are determined using the D8 Advance X-ray powder diffraction device (manufacturer: Bruker, USA). The oven-dried sample $(2-3 \mathrm{~g})$ that passed through a $75 \mu \mathrm{m}$ sieve has been used for the analysis. The sample preparation involves spreading the powder sample uniformly on the sample holder and then mounting the holder on the platform carefully. The sample is scanned for reflections with a voltage and current of $40 \mathrm{kV}$ and $40 \mathrm{~mA}$, respectively; with $2 \theta$ ranging from 5 to $80^{\circ}$ with a step size of $0.025^{\circ}$; and with a time interval $0.5 \mathrm{~s}$ for each step by using an $\mathrm{X}$-ray tube with a copper anode. The presence of minerals was identified with the help of the Diffrac.Suite Eva software. The software identifies the mineral phases based on peak search and matching these with a standard pattern of $d$-spacing of minerals based on the given input chemical elements or composition.

The morphological characteristics are established using a Merlin compact field-emission scanning electron microscope (manufacturer: Zeiss, Germany). For this purpose, a small amount of oven-dried red mud that has passed through a $75 \mu \mathrm{m}$ sieve is used. Prior to testing, samples have been sputtered with gold using a Q150R ES sputter coater (manufacturer: Quorum, UK), which helps in revealing the superior morphological characteristics of red mud particles. Additionally, the elemental compositions of RMW have also been determined using the energy-dispersive spectroscopy (EDS) technique, which has been integrated along with scanning electron microscopy (SEM). The EDS data are acquired using the Inca software (Oxford Instruments, UK).

\section{Results}

\section{Physical characteristics}

The various physical and geotechnical properties obtained for the RMW used in the study are presented in Table 1 . The value of specific gravity is measured as $3 \cdot 05$, which is found to be much higher than those of natural soils and conforms to the results reported by Sundaram and Gupta (2010) and Newson et al. (2006). The presence of oxides/minerals belonging to the iron (Fe) family (i.e. goethite and haematite minerals) may be the likely reason for such a higher value of specific gravity ( $\mathrm{Li}, 1998$; Newson et al., 2006). The particle size distribution reveals that $95 \%$ of the particles are finer than $75 \mu \mathrm{m}$, with a majority of particles, about $68 \%$, falling within the silt size range. About $27 \%$ of particles are identified to fall within the clay size range, and the remaining $5 \%$ are found within the sand size range. The percentage fractions identified for the waste are comparable with the results reported by Sundaram and Gupta (2010) and Parekh and Goldberger (1976). The consistency limits show a reasonably high value of liquid limit, equal to $41 \%$, with a small plasticity index of $5 \%$. As per USCS, RMW is classified as inorganic silt of low plasticity (ML). Gray and Somogyi (1974) also reported a similar kind of classification scheme for RMW. The activity value of red mud is calculated as $0 \cdot 22$, which categorises the waste as inactive (i.e. activity $<0 \cdot 75$ ). This observation is in agreement with the findings of Rubinos et al. (2015). It has been observed that the activity value of RMW is closer to that of calcite and mica $(=0 \cdot 2)$ minerals and is comparable to that of the muscovite $(\approx 0 \cdot 25)$ mineral, but lower than that of the kaolinite $(\approx 0 \cdot 4)$ mineral (Mitchell, 1976; Skempton, 1953). A typical comparison of various physical properties of RMW with other wastes (i.e. fly ash) and natural soils is listed in Table 1. It can be noted that the tabulated values for the waste and natural soils are relevant to acceptability criterion set by different standards to select a soil/waste in the construction of an embankment.

\section{Compaction characteristics}

Figure 1 shows dry unit weight against water content relationships for samples of untreated RMW established by conducting a series 


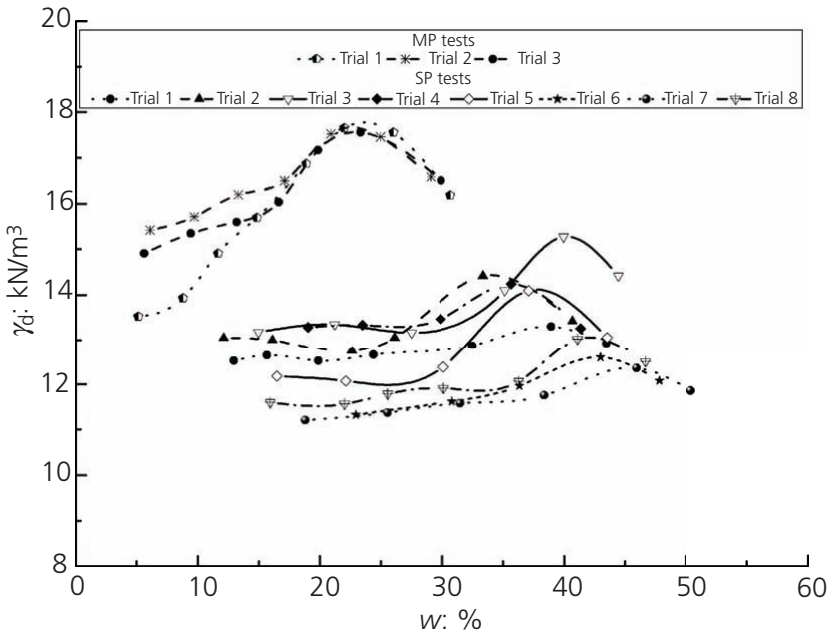

Figure 1. Dry unit weight plotted against water content relationships for samples of untreated RMW (Reddy and Rao, 2016)

of SP and MP tests on several identical samples. It can be observed from the trends that only MP tests yield consistent values of maximum dry unit weight $\gamma_{\mathrm{dmax}}$ at low optimum water content $w_{\text {opt }}$. In contrast, considerable variations in the values of $\gamma_{\mathrm{dmax}}$ and $w_{\text {opt }}$ can be seen corresponding to SP tests, although identical samples have been used for testing. It can be observed from the plots that the compaction curves are smooth and their peaks are marginally flat, resembling the typical compaction characteristics of clayey soils (Terzaghi et al., 1996). In SP tests, the values of $\gamma_{\mathrm{dmax}}$ varied relatively in a lower range from 12.5 to $15 \cdot 5 \mathrm{kN} / \mathrm{m}^{3}$, while $w_{\text {opt }}$ varied over a wide range from 34 to $45 \%$, respectively. As expected, MP tests yield significantly large dry unit weight values in comparison to SP tests. A general observation of the values of $\gamma_{\mathrm{dmax}}$ obtained by resorting to SP tests reveals that they are slightly on the lower side compared to those of conventional soils, whose typical dry unit weight usually begins from $16 \mathrm{kN} / \mathrm{m}^{3}$ onwards (Holtz and Kovacs, 1981). This may be attributed to the fact that the presence of caustic soda, which imparts high alkalinity to the waste, seems to be affecting the compaction behaviour of RMW. Incidentally, the effect of alkalinity on the density results pertaining to MP tests is found to be almost negligible. This demonstrates that the densification of RMW requires a relatively high compactive effort.

As such, huge variations in the values of $\gamma_{\mathrm{dmax}}$ and $w_{\mathrm{opt}}$ (refer to Figure 1) imply that they may be affected with change in compaction energy. Thus, to understand the effect of compaction energy in a detailed way, Proctor tests were performed on identical samples by varying the compaction energy in terms of the number of blows. The compaction curves have been established starting from a minimum of 12 blows per layer and increased subsequently to reach a maximum of 56 blows per layer, which mimics the MP test. The number of blows between any two successive trials has been chosen based on the study of Sridharan and Sivapullaiah (2005). Figure 2 depicts the variations in compaction energy, which has been calculated for a given number of blows, plotted against $\gamma_{\mathrm{dmax}}$ and $w_{\mathrm{opt}}$. The contrast in unit weight values, as similarly with the case of SP tests, is evident from the trends. From the graphs (refer to Figure 2), an increase in $\gamma_{\text {dmax }}$ and decrease in $w_{\text {opt }}$ with an increase in compaction energy can be observed. This highlights that the dry unit weight against water content relationship of untreated RMW is sensitive to the applied compaction energy. As depicted in Figure 2, there is a reasonable increase in dry unit weight and decrease in $w_{\text {opt }}$ when the compaction energy is varied from 285 to $2595 \mathrm{~kJ} / \mathrm{m}^{3}$. As such, the results demonstrate that relatively higher compaction energy, which may be equivalent to MP test, is essential to densify the alkaline RMW in all the field applications. Incidentally, this statement may be valid for all practical cases, including those of less important field applications such as rural road construction. The results discussed herein confirm that the presence of caustic content in RMW affects its compaction behaviour.

In order to mitigate the effect of alkalinity, many researchers proposed for neutralisation or treatment of RMW to use a suitable additive/neutralising agent such as seawater, acid and carbon dioxide (Khaitan et al., 2010; Rai et al., 2013). However, no attempts have been made to establish the compaction characteristics of neutralised or treated RMW to date. With this in mind, efforts are devoted in the present study to evaluate the
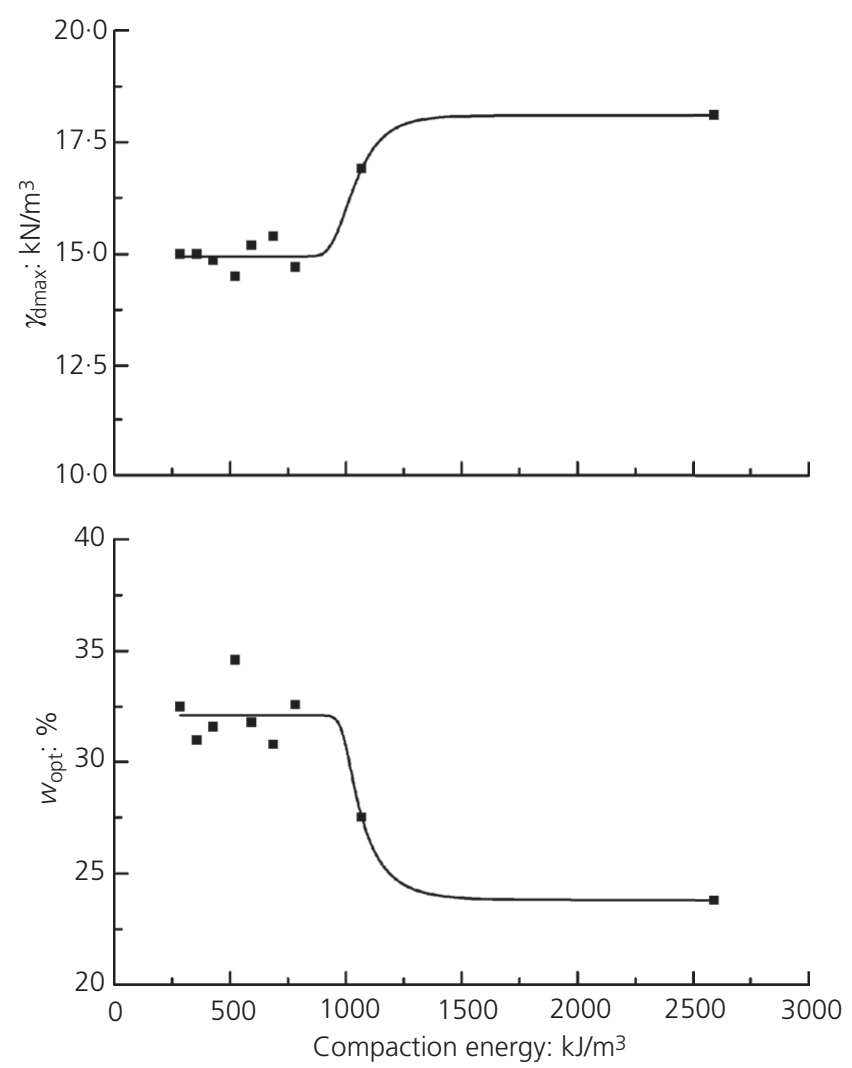

Figure 2. Variations in $\gamma_{\mathrm{dmax}}$ and $w_{\mathrm{opt}}$ with compaction energy for samples of untreated RMW (Reddy and Rao, 2016) 
compaction characteristics of RMW after treatment with sodium chloride and hydrochloric acid solutions of different concentrations. To achieve this, a series of SP and MP tests have been conducted on RMW samples treated with $(a) 1.71$ and $3.42 \mathrm{M}$ sodium chloride solutions and (b) hydrochloric acid solutions with $\mathrm{pH}$ of $1,1 \cdot 5$ and 2 , respectively.

Figure 3 shows results of dry unit weight against water content relationships established by resorting to SP and MP tests on samples treated with chemical solutions. Neither of the chemical treatments showed improvement in unit weight values, but a slight decrease in optimum water content can be observed. However, the compaction behaviour of treated RMW remains unaffected, as the peaks of the curves appear flat and identical to those of untreated samples (refer to Figure 1). The values of $\gamma_{\mathrm{dmax}}$ are found to be varying in the range of $13 \cdot 5-14.8 \mathrm{kN} / \mathrm{m}^{3}$ for SP tests and $16 \cdot 5-19 \cdot 0 \mathrm{kN} / \mathrm{m}^{3}$ for MP tests. It is also evident from the trends that the sodium chloride-treated samples exhibit dry unit weight values slightly higher than those of the hydrochloric acid-treated samples. However, the overall difference in values of $\gamma_{\mathrm{dmax}}$, when comparing untreated with treated samples, is almost trivial, corresponding to both SP and MP tests.

Based on the findings discussed herein, attempts were also made to explore the suitability of the waste in various practical applications. For this purpose, the data of $\gamma_{\mathrm{dmax}}$ and $w_{\mathrm{opt}}$ obtained from all tests of the present study and the range of $\gamma_{\mathrm{dmax}}$ and $w_{\mathrm{opt}}$ values specified by different codes for a soil/waste material to select it for use in road and/or in embankment construction are compiled and listed in Table 2. A critical comparison of the results listed in the table reveals that the dry unit weight values obtained from SP tests only conform to the specifications of the Ministry of Rural Development (MoRD, 2014) and IS 1498-1970 (BIS, 2007). Both of these codes specify a

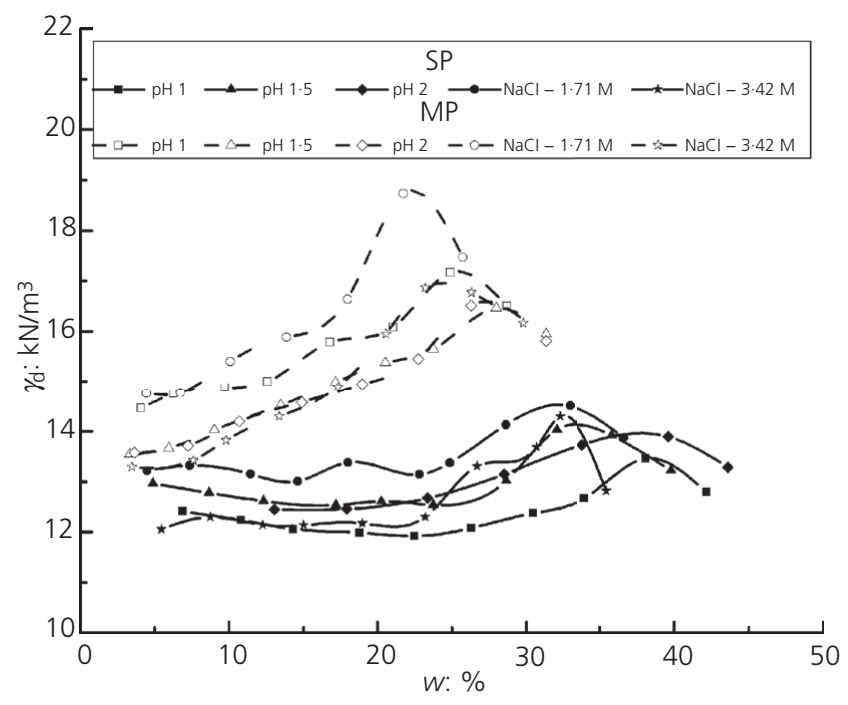

Figure 3. Compaction curves of treated RMW samples established by SP and MP tests (modified after Reddy and Rao (2016)) minimum dry unit weight of $14.4 \mathrm{kN} / \mathrm{m}^{3}$ desired for a material to be chosen for the construction of an embankment (MoRD, 2014) or a road (IS 1498-1970 (BIS, 2007)). As such, the former code proposes specifications with regard to the construction of rural roads, while the latter one deals with classification and identification of soils for general engineering purposes. Incidentally, the dry unit weight values reported for the present study fall in a well acceptable range of the IRC SP 58-2001 standard specified for a fly ash material (IRC, 2001b). It is important to note that dry unit weight values obtained from MP tests on both untreated and treated samples excellently corroborate with all code specifications listed in the table. Thus, it can be stated that RMW can become an excellent resource material in the construction of rural roads and embankments when packed densely by applying higher compaction energy (say equal to that of the MP test). Another important observation that can be seen from the results is that the chemically treated samples exhibit consistent dry unit weight values against untreated samples. This bears a practical significance, as repeatability often plays a vital role in the selection of a particular material in a practical application.

Additionally, efforts were also devoted to evaluate critically the compaction behaviour of RMW by comparing results of the study with those of industrial solid waste and municipal solid waste (MSW) as well as soils treated with chemicals (calcium sulfate in this case). Figure 4 shows the compaction characteristics of various industrial solid wastes and MSW and soils treated with chemicals. The types of different wastes used for comparison purposes along with their reported $\gamma_{\mathrm{dmax}}$ and $w_{\text {opt }}$ values are listed in Table 3. It can be seen from Figure 4 that compaction curves of RMW are quite close to those of industrial wastes such as jarosite and coal wash and that of calcium sulfate $\left(\mathrm{CaSO}_{4}\right)$-treated soils. In addition, it can also be observed that compaction curves of RMW lie between those of industrial wastes (viz. crushed brick, steel furnace slag, copper slag and zinc slag) and MSW. The following observations can also be made from the trends depicted in Figure 4: (a) industrial wastes yield compaction curves with a sharp peak with notably higher dry unit weight at extremely low optimum water content; (b) contaminated soils, including RMW, show a smooth and flat peak with moderate dry unit weight at marginally high optimum water content; and (c) MSW shows compaction curves with a broadened peak with substantially high optimum water content at a far lower dry unit weight.

\section{Consolidation characteristics}

In addition to the compaction characteristics discussed earlier, the consolidation characteristics were also established before and after treatment of the waste with sodium chloride and hydrochloric acid solutions. The consolidation characteristics include determination of the net change in void ratio $\Delta e$, compression index $c_{\mathrm{c}}$ and coefficient of volume change $m_{\mathrm{v}}$. Figure 5 shows the relationship between void ratio $e$ and applied pressure $p$ for both untreated and treated samples during loading and unloading conditions. The loading curves depict a continuous decrease in the void ratio, indicating compression or settlement in the sample, with an increase in applied pressure. However, the dilation in samples upon 


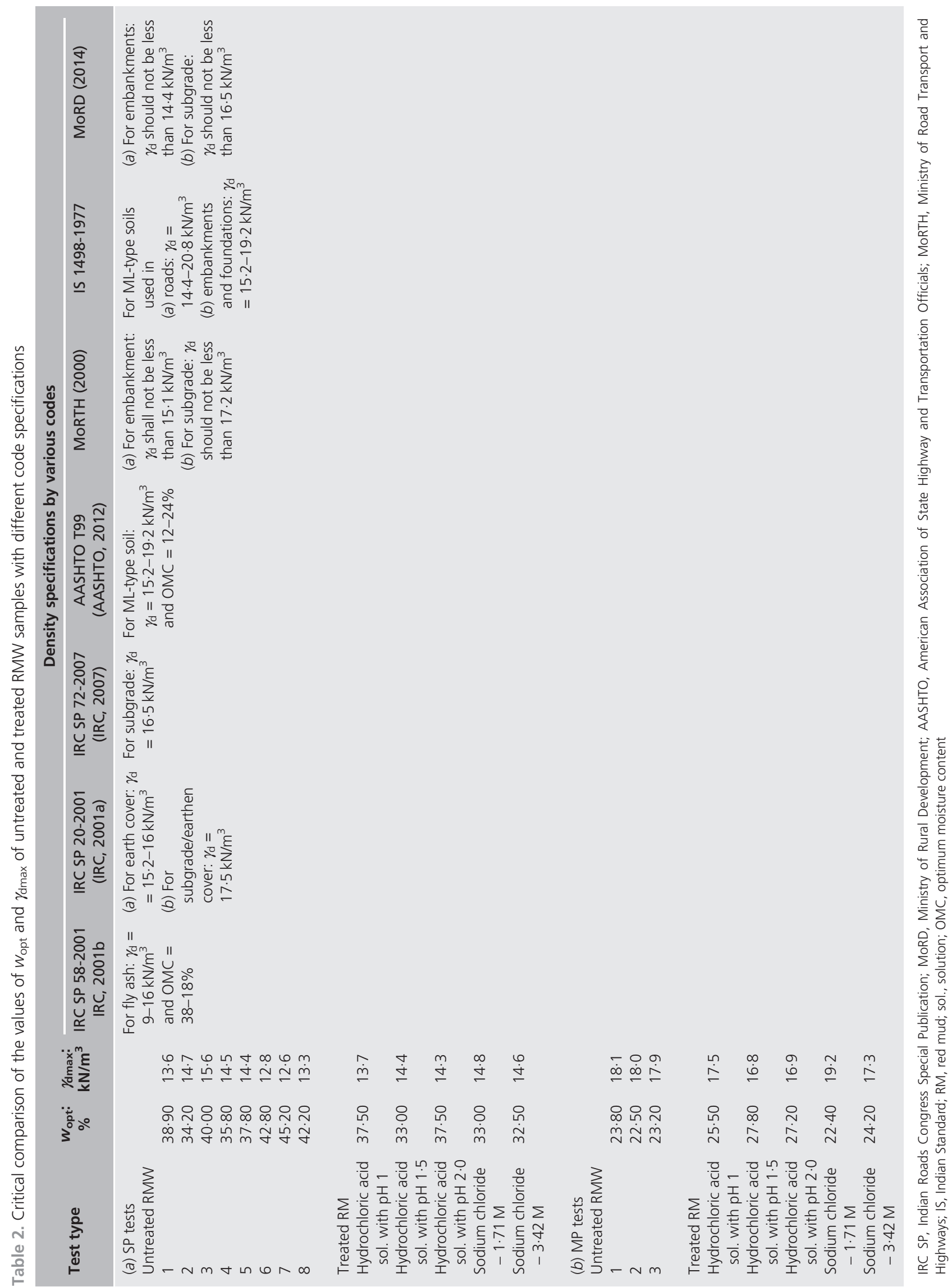




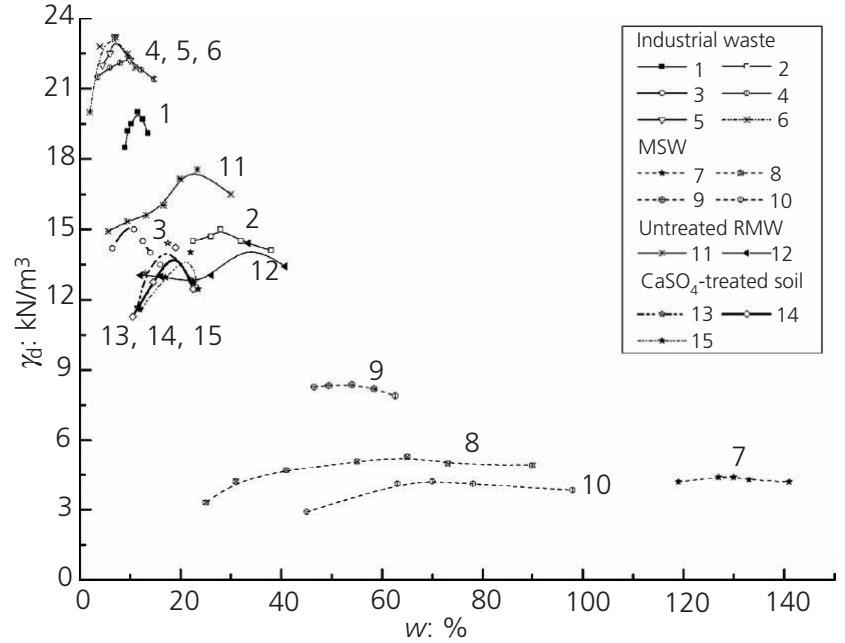

Figure 4. Compaction characteristics of various wastes and chemically treated soils

unloading appears to be insignificant. As depicted in the figure, the $e$ against $\log (p)$ relationship is non-linear in nature, describing a change in strain rate despite a constant increase in stress (Holtz and Kovacs, 1981). For validation of the present results, similar findings reported by Newson et al. (2006), who established the $e-\log (p)$ relationship for acid-washed RMW, are superimposed on the results in Figure 5. It can be observed from the graphs that the natures of both trends characteristically appear identical, validating the consolidation behaviour of RMW used in the study.

Using the obtained $e$ against $\log (p)$ graphs, as depicted in Figure 5 , the net change in the void ratio (i.e. $\Delta e=$ initial void ratio - final void ratio) caused due to loading and unloading is computed, and the results obtained are shown in Figure 6(a) in the form of a bar chart and are also listed in Table 4. The results presented herein (Figure 6) can directly help in comprehending

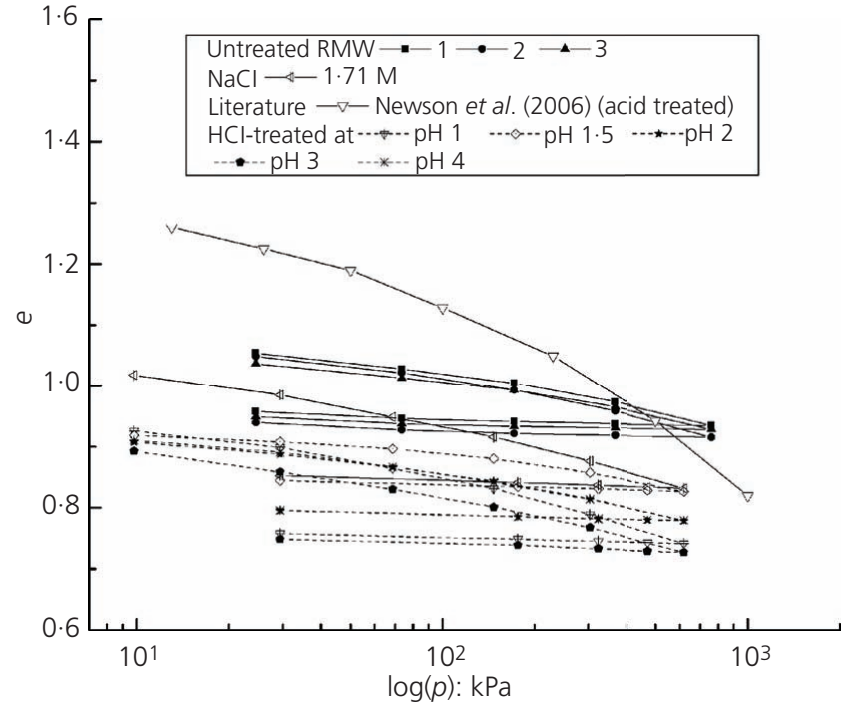

Figure 5. e-log(p) curves for untreated and treated RMW samples

the effect of chemical agents on the compressibility behaviour of RMW. The compression behaviour in increasing order is found as sodium chloride $>$ hydrochloric acid $>$ untreated RMW. Evidently, the values of $\Delta e$ for both untreated and treated samples are observed to be appreciably lower than that of conventional soils (Rubinos et al., 2015). Generally, in waste materials, the compression mechanism is controlled by applied stresses and changes in physico-chemical processes (Liu et al., 2006; Sowers, 1973). Interestingly for RMW, the net volume change with applied stress is appreciably low and there is also a slight variation in $\Delta e$ with a change in $\mathrm{pH}$, indicating a definite influence of $\mathrm{pH}$ on compressibility characteristics.

Further, the values of the compression index $c_{\mathrm{c}}$ and coefficient volume change $m_{\mathrm{v}}$ are also computed using the data presented in Figure 5, and their variations for different treatment conditions are

Table 3. Legend and reference for the data used in the Figure 4

\begin{tabular}{|c|c|c|c|c|}
\hline Legend & Name of the waste & Reference & $w_{\text {opt: }}: \%$ & $\gamma_{\text {dmax }}: \mathrm{kN} / \mathrm{m}^{3}$ \\
\hline 1 & Crushed brick & Mohammadinia et al. (2015) & $11 \cdot 40$ & $20 \cdot 00$ \\
\hline 2 & Jerosite & Sinha et al. (2013) & 28.00 & $15 \cdot 00$ \\
\hline 3 & Coal wash & Rujikiatkamjorn et al. (2012) & $10 \cdot 80$ & $15 \cdot 00$ \\
\hline 4 & Steel furnace slag & & $9 \cdot 50$ & $22 \cdot 30$ \\
\hline 5 & Copper slag & Havanagi et al. (2012) & $7 \cdot 00$ & $23 \cdot 20$ \\
\hline 6 & Zink slag & & $7 \cdot 00$ & $23 \cdot 20$ \\
\hline 7 & Spent coffee ground & Arulrajah et al. (2014) & $130 \cdot 00$ & $4 \cdot 40$ \\
\hline 8 & MSW & Hanson et al. (2010) & $65 \cdot 00$ & $5 \cdot 30$ \\
\hline 9 & Biosolids & Arulrajah et al. (2013) & $49 \cdot 50$ & $8 \cdot 40$ \\
\hline 10 & MSW & Reddy et al. (2009) & $70 \cdot 00$ & $4 \cdot 20$ \\
\hline 11 & RM-MP & Present study & $23 \cdot 80$ & $18 \cdot 10$ \\
\hline 12 & RM-SP & & $34 \cdot 20$ & $14 \cdot 42$ \\
\hline 13 & Soil with $1 \%$ calcium sulfate & Vipulanandan and Mohammed (2016) & $17 \cdot 50$ & $14 \cdot 42$ \\
\hline 14 & Soil with $2 \%$ calcium sulfate & & $19 \cdot 00$ & $14 \cdot 22$ \\
\hline 15 & Soil with $4 \%$ calcium sulfate & & $22 \cdot 00$ & $14 \cdot 00$ \\
\hline
\end{tabular}

MSW, municipal solid waste; RM-MP, red mud - modified Proctor; RM-SP, red mud - standard Proctor 
Compaction and consolidation behaviour of untreated and treated waste of Indian red mud

Reddy and Rao

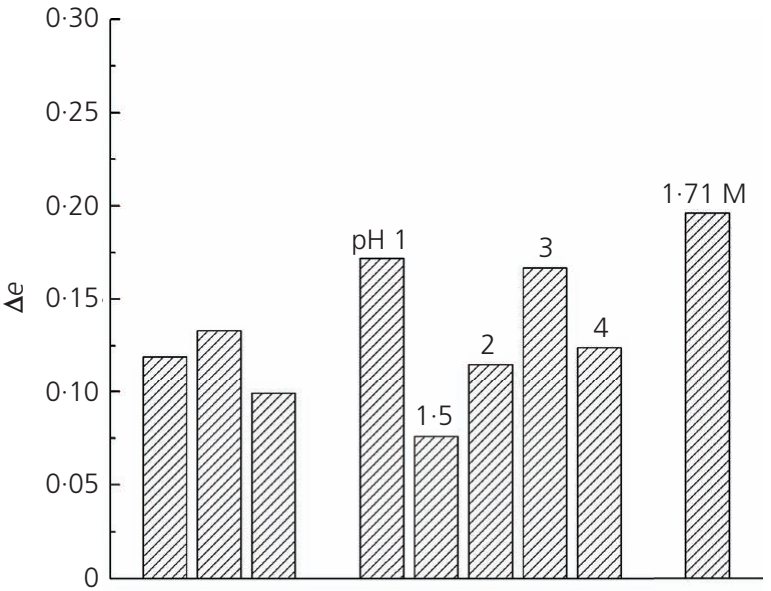

(a)

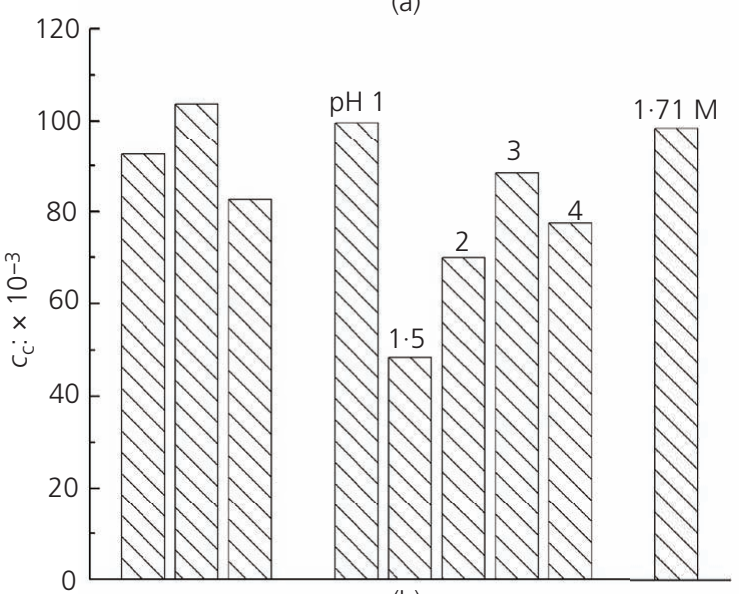

(b)

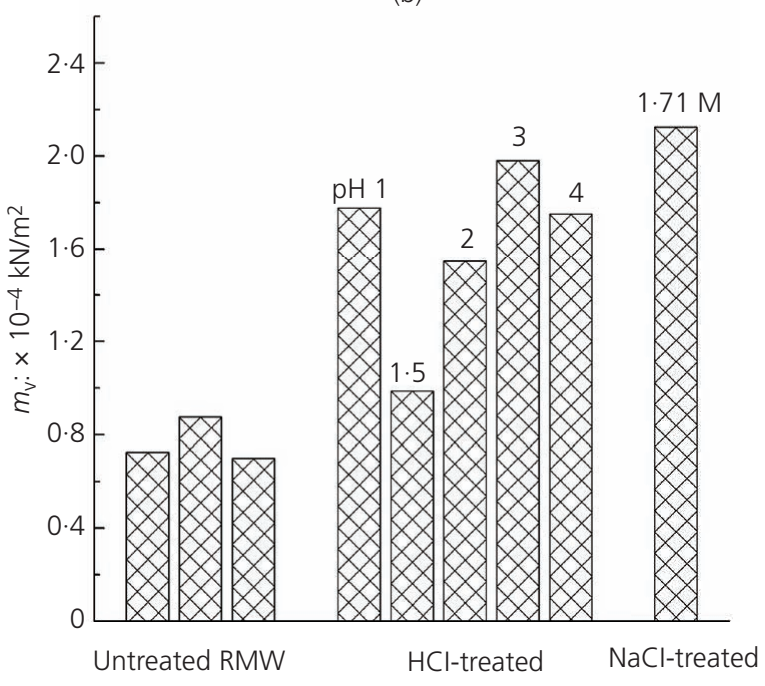

(c)

Figure 6. The measured values of (a) $\Delta e,(b) c_{c}$ and (c) $m_{v}$ for untreated and treated samples

depicted in Figures 6(b) and 6(c) in the form of bar charts. The values of $c_{\mathrm{c}}$ and $m_{\mathrm{v}}$ are also listed in Table 4. For critical comparison, the values of $c_{\mathrm{c}}$ reported for other waste types are also summarised in the table. The results in Figure 6(b) show a marginal variation in $c_{\mathrm{c}}$ between untreated and treated samples. In contrast, a significant variation in the values of $m_{\mathrm{v}}$ between untreated and treated samples can be observed. Importantly, results in Figures 6(b) and 6(c) reveal that $\mathrm{pH}$ can affect both the $c_{\mathrm{c}}$ and $m_{\mathrm{v}}$ parameters to a significant extent, as they varied considerably with a change in $\mathrm{pH}$ of the compaction pore fluid. This indicates that the treatment of waste using the chemicals such as hydrochloric acid and sodium chloride affects the final settlement of RMW. The order in the increase in $m_{\mathrm{v}}$ is found as sodium chloride $>$ hydrochloric acid $>$ untreated RMW. The minimum and maximum values of indices were calculated as 0.048 and $0 \cdot 1$, respectively. The very low value of $c_{\mathrm{c}}$ means that the waste resists compression and, thereby, it undergoes low settlement similar to that of industrial wastes. The observed values of $c_{\mathrm{c}}$ for RMW (refer to Table 4) are found to be consistent with those reported for other waste types such as fly ash, bottom ash, lime sludge and alluvial soil (Ministry of Railways, 2006; Srivastava, 1997).

Further, to examine the influence of the initial void ratio $e_{0}$ on the compressibility characteristics of RMW, its values are plotted against $c_{\mathrm{c}}$, as depicted in Figure 7 (Table 5). For comparison, data belonging to fly ash and RMW generated by other sources are also superimposed on the graph. Results show that the compression index increases with an increase in the initial void ratio. However, data pertinent to the present study reveal only a slight increase in $c_{\mathrm{c}}$ with an increase in $e_{0}$, indicating that the change in the initial void ratio does not have much influence on the compressibility of RMW. Similarly, Figure 7 shows a good agreement of the results of the present study with literature data. It is obvious that the relationship between the compression index and void ratio is linear in nature.

\section{Discussion}

In general, soils under flocculent state have a low unit weight and a high void ratio and, consequently, show a low density (Lambe, 1960). In the case of RMW, samples compacted using sodium chloride as the compaction fluid exhibited a high dry unit weight at low optimum water content compared with samples compacted using the counterpart agent hydrochloric acid (refer to Figure 3 and Table 2). This may be due to the substitution of water molecules by salts, which would have decreased the moisture content and increased the lubricating effect, leading to denser packing of particles with a dispersed-like structure, giving higher unit weight. This observation corroborates the findings of Azadi (2008), Mansour et al. (2008) and Alainachi and Alobaidy (2010), who studied the effect of salinity on the compaction results and showed that the OMC of the soil decreases and its maximum dry unit weight increases when saline water is used as the compaction fluid. Generally, alkaline solutions such as caustic soda are characterised to induce a slippery effect on the particles' surface. As such, RMW contains a substantial amount of caustic soda, which is believed to have such a slippery effect on particles' surface. When hydrochloric acid is added to caustic soda, the following chemical reaction occurs, as expressed herein 
Table 4. Comparison of the values of $\Delta e_{,} c_{c}$ and $m_{v}$ obtained for untreated and treated RMW samples with the literature data

\begin{tabular}{|c|c|c|c|c|c|c|c|c|}
\hline \multirow{2}{*}{ Sample } & \multicolumn{5}{|c|}{ Compression index $c_{\mathrm{c}}: \times 10^{-3}$} & \multicolumn{2}{|c|}{$\begin{array}{l}\text { Coefficient of volume } \\
\text { change } m_{\mathrm{v}}: \times 10^{-4} \mathrm{~m}^{2} / \\
\mathrm{kN}\end{array}$} & \multirow{2}{*}{$\begin{array}{c}\text { Net change } \\
\text { in void ratio } \\
\Delta e \\
\begin{array}{c}\text { Present } \\
\text { study }\end{array}\end{array}$} \\
\hline & $\begin{array}{l}\text { Present } \\
\text { study }\end{array}$ & $\begin{array}{c}\text { Average } \\
\text { value of } \\
\text { present study }\end{array}$ & Srivastava (1997) & $\begin{array}{l}\text { Tu et al. } \\
\text { (2007) }\end{array}$ & $\begin{array}{c}\text { GE 0-S005 } \\
\text { (Ministry of } \\
\text { Railways, 2006) }\end{array}$ & $\begin{array}{l}\text { Present } \\
\text { study }\end{array}$ & $\begin{array}{c}\text { Average } \\
\text { value of } \\
\text { present study }\end{array}$ & \\
\hline $\begin{array}{l}\text { Untreated } \\
\text { RM-1 }\end{array}$ & $92 \cdot 54$ & $92 \cdot 94$ & $\begin{array}{l}11 \cdot 7 \text { for RM, } 17 \cdot 1 \text { for } \\
\text { FA, } 49 \cdot 8 \text { for } L S \text { and } 28 \cdot 3\end{array}$ & $\begin{array}{l}39-64 \\
\text { for class- }\end{array}$ & $\begin{array}{l}6.74-20.86 \text { for } F A \\
\text { and } 24.28 \text { for BA }\end{array}$ & 0.725 & 0.767 & $0 \cdot 120$ \\
\hline $\begin{array}{l}\text { Untreated } \\
\text { RM-2 }\end{array}$ & $103 \cdot 63$ & & for AS & FFA & & 0.877 & & $0 \cdot 133$ \\
\hline $\begin{array}{l}\text { Untreated } \\
\text { RM-3 }\end{array}$ & $82 \cdot 64$ & & & & & 0.699 & & $0 \cdot 100$ \\
\hline $\begin{array}{l}\text { Hydrochloric } \\
\text { acid sol. at } \\
\text { pH } 1\end{array}$ & $99 \cdot 63$ & $76 \cdot 75$ & & & & $1 \cdot 778$ & 1.609 & $0 \cdot 172$ \\
\hline $\begin{array}{l}\text { Hydrochloric } \\
\text { acid sol. at } \\
\text { pH } 1.5\end{array}$ & $48 \cdot 42$ & & & & & 0.988 & & 0.076 \\
\hline $\begin{array}{l}\text { Hydrochloric } \\
\text { acid sol. at } \\
\mathrm{pH} 2\end{array}$ & $69 \cdot 90$ & & & & & $1 \cdot 547$ & & $0 \cdot 115$ \\
\hline $\begin{array}{l}\text { Hydrochloric } \\
\text { acid sol. at } \\
\text { pH } 3\end{array}$ & $88 \cdot 33$ & & & & & 1.982 & & $0 \cdot 167$ \\
\hline $\begin{array}{l}\text { Hydrochloric } \\
\text { acid sol. at } \\
\mathrm{pH} 4\end{array}$ & $77 \cdot 47$ & & & & & 1.751 & & $0 \cdot 124$ \\
\hline $\begin{array}{l}\text { Sodium } \\
\text { chloride - } \\
1.71 \mathrm{M}\end{array}$ & $98 \cdot 21$ & $98 \cdot 21$ & & & & $2 \cdot 127$ & $2 \cdot 127$ & $0 \cdot 197$ \\
\hline
\end{tabular}

RM, red mud; FA, fly ash; LS, lime sludge; AS, alluvial soil; BA, bottom ash

I. $\mathrm{NaOH}(\mathrm{aq})+\mathrm{HCl}(\mathrm{aq}) \rightarrow \mathrm{NaCl}(\mathrm{aq})+\mathrm{H}_{2} \mathrm{O}$

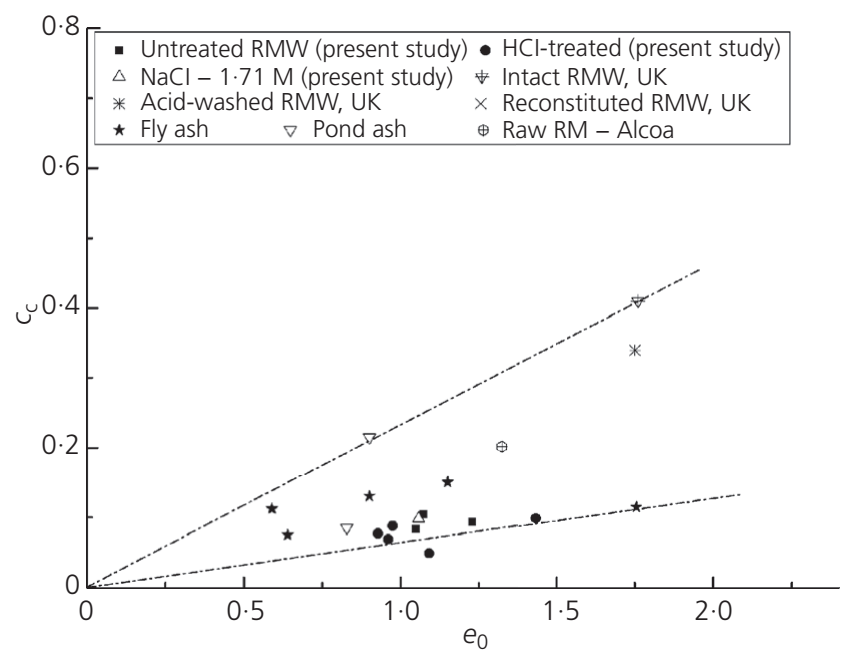

Figure 7. Compression index against initial void ratio for fly ash and untreated and treated samples of RMW
The excess generated water tries to fill up the voids, resulting in a higher optimum water content, as depicted in Figure 3. However, nothing happens chemically between caustic soda and sodium chloride, but the dissolved caustic soda reduces the amount of sodium chloride that can dissolve in pore solution because caustic soda is more soluble than sodium chloride. Also, there is a common ion effect (i.e. sodium ion $\left(\mathrm{Na}^{+}\right)$) between these two chemicals. From Figure 3, it can be observed that the samples when treated with hydrochloric acid solutions yield a lower dry unit weight at high water contents compared with that of sodium chloride-treated samples. This may be due to immediate flocculation and agglomeration of particles caused by cation exchange, leading to a decrease in the dry unit weight. When hydrochloric acid is mixed with the waste, it is the aluminium (Al) ions, which could have liberated as a result of breakdown of particles, rather than the hydrogen ions, that control the unit weight. Usually, soils containing a significant amount of weakly bonded cations such as sodium show a tendency to absorb and retain large quantities of water. This could be one of the reasons for both untreated and treated RMW samples (refer to Figures 1 and 3) exhibiting large values of $w_{\text {opt }}$.

Further, slightly higher values of $c_{\mathrm{c}}$ and $m_{\mathrm{v}}$ corresponding to samples treated with sodium chloride can be observed from the results presented in Table 4 . This may be attributed to an excess 
Table 5. Legend and reference for the data used in the Figure 7

\begin{tabular}{|c|c|c|c|c|}
\hline Sample number & Material type (RM/FA) & Reference & $c_{c}$ & $e_{0}$ \\
\hline 1 & Untreated RMW & Present study & 0.0933 & $1 \cdot 116$ \\
\hline 2 & Hydrochloric acid-treated RMW & & $0.0766^{a}$ & $1.079^{a}$ \\
\hline 3 & Sodium chloride-treated RMW & & 0.098 & 1.057 \\
\hline 4 & Untreated RM, UK & Newson et al. (2006) & 0.41 & 1.76 \\
\hline 5 & Acid-washed RM, UK & & $0 \cdot 34$ & $1 \cdot 75$ \\
\hline 6 & Reconstituted RM, UK & & $0 \cdot 34$ & $1 \cdot 75$ \\
\hline 7 & Untreated RM, Alcoa, San Cibrao & Rubinos et al. (2015) & $0 \cdot 202$ & $1 \cdot 323$ \\
\hline 8 & Fly ash, Kolaghat, India & Pal and Ghosh (2014) & $0 \cdot 112$ & 0.59 \\
\hline 9 & Fly ash, India & Madhyannapu et al. (2008) & $0 \cdot 15$ & $1 \cdot 15$ \\
\hline 10 & Fly ash, India & McLaren and Digioi (1987) & $0 \cdot 13$ & 0.9 \\
\hline 11 & Fly ash, India & Raza et al. (1999) & $0 \cdot 116$ & $1 \cdot 755$ \\
\hline 12 & Fly ash (class C), Raichur, India & Babu and Jaladurgam (2014) & 0.075 & $0 \cdot 64$ \\
\hline 13 & Pond ash, Kolaghat & Pal and Ghosh (2014) & 0.085 & 0.828 \\
\hline 14 & Pond ash & Sinha et al. (1998) & 0.215 & 0.9 \\
\hline
\end{tabular}

${ }^{a}$ Average values

FA, fly ash

lubrication effect, causing changes in the particles' arrangement when sodium chloride solution is used as the pore fluid in consolidation tests, resulting in greater compressibility. This observation conforms to the results of Di Maio (1996) and Di Maio and Fenelli (1994), who reported that the strength and compressibility of platy clay minerals increases after the introduction of saline pore fluid. Moreover, there may be an effect of viscosity of pore fluids on the compressibility properties of RMW. The viscosity of water is $1.193 \mathrm{cP}$, while that of sodium chloride solution is slightly lower at $1 \mathrm{cP}$. The decrease in the viscosity of pore fluid may result in an increase in the rate of consolidation due to rapid drainage (Paaswell, 1967). Also, the results presented in the Figure 6 show some abnormal changes in the values of $c_{\mathrm{c}}$ and $m_{\mathrm{v}}$ when treated using hydrochloric acid solutions at different $\mathrm{pH}$ levels. This unusual change in compressibility characteristics may be attributed to chemical and mineralogical changes that might have occurred due to $\mathrm{pH}$ change (Sivapullaiah and Reddy, 2009).

In order to examine the possible influence of chemical and mineralogical compositions on compaction and compressibility characteristics, these properties were established on post-treated

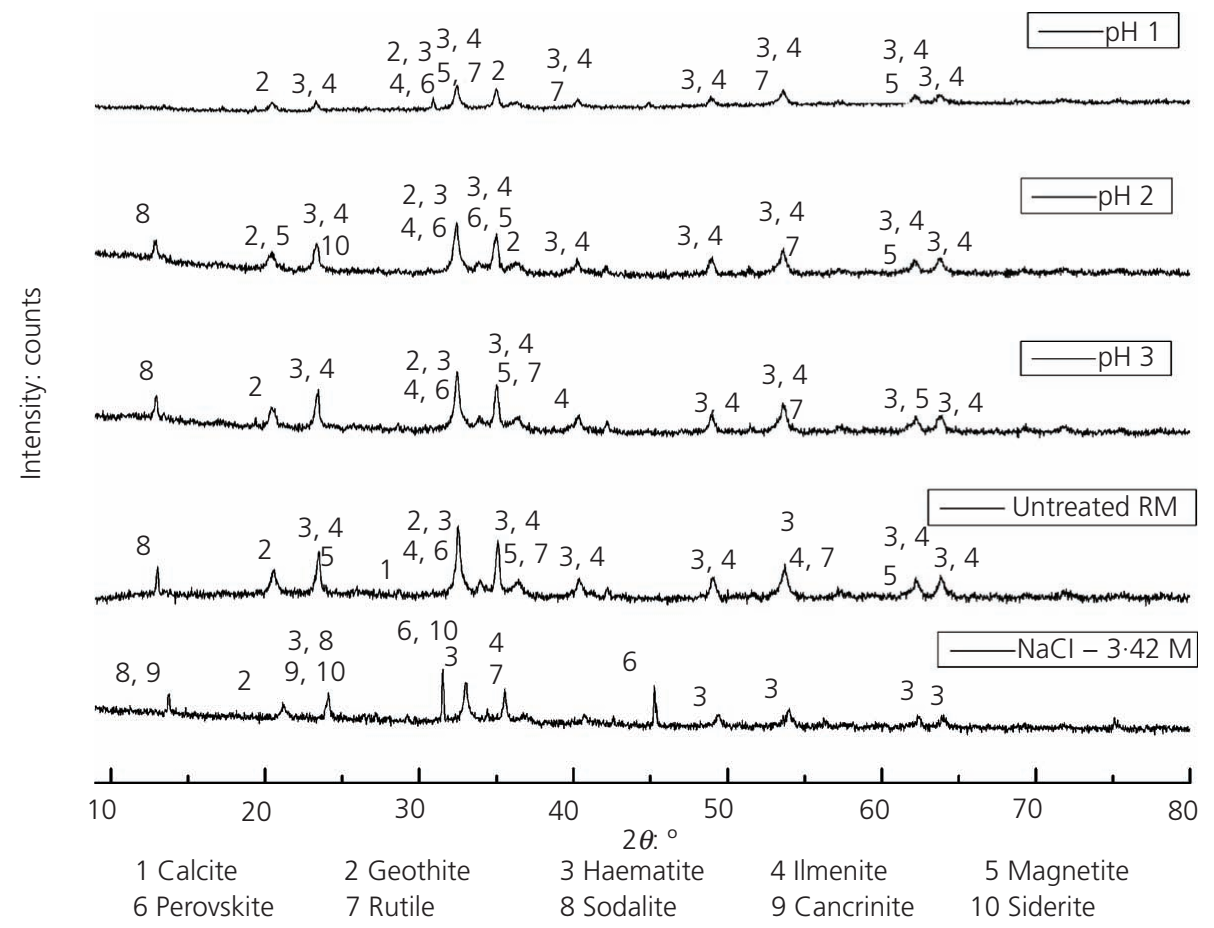

Figure 8. X-ray diffraction patterns of various treated and untreated RMW samples 
hydrochloric acid and sodium chloride samples, as depicted in Figures 8 and 9, respectively. From Figure 8, a complete absence of reflections belonging to the calcite mineral can be seen between untreated and treated samples for all $\mathrm{pH}$ conditions. In addition, considerable variations in the peak intensity of reflections belonging to other mineral phases are also visible from the patterns when treated samples are compared with those of untreated samples. Moreover, the formation of new mineral phases such as cancrinite and siderite can also be witnessed for the samples treated with sodium chloride solution. As such, phase transformations that might have occurred with the change in $\mathrm{pH}$ may be a likely reason for variations in the values of $c_{\mathrm{c}}$ and $m_{\mathrm{v}}$ as well as variations in dry unit weight and optimum water content.

Figure 9 shows the results of percentage composition of various elements measured using the EDS technique on samples treated with different solutions. The analysis is carried out on dry powder samples obtained by drying the supernatant prepared by mixing RMW and liquid in a 1-to-10 ratio. However, EDS tests are not performed on sodium chloride-treated samples due to problems encountered on obtaining the representative samples. As depicted in the figure, the majority of elements found in the waste are not harmful in nature. However, there is a significant variation in the percentage composition of different elements among the samples treated with different solutions. As such, when tap water is used as compaction fluid, which is a commonly used liquid in all the practical scenarios, trapping of almost all the elements can be observed without any significant release. Interestingly, retention of fluoride and chloride elements by RMW is considerable when tap water is used as compaction fluid. Thus, the results of the study suggest the use of tap water for compaction and compressibility purposes of RMW. But there is no release of chloride, and considerable percentage release of fluoride can be witnessed at extremely low $\mathrm{pH}$ values $(<3)$. Generally, the ratio of calcium $(\mathrm{Ca})$ and silicon $(\mathrm{Si})$ dictates the $\mathrm{pH}$ of the medium and so plays a dominant role in the leachability of most elements from the waste material (Izquierdo and Querol, 2012). However, alkalinity contributes to attenuating the leachability of a large number of heavy metals (Edil et al., 1992; Toth et al., 1988). As such, RMW well fits in the category of high alkaline waste material, and it can be ensured that the leachability of heavy metals, if any, may be at attenuated levels. However, extensive studies in this direction are required to quantify the exact influence of chemical and mineralogical compositions on the compaction and compressibility characteristics of RMW.

Studies demonstrate that particles' shape, particles size, surface charge properties and constituent minerals are some key factors that influence compressibility and compaction characteristics of a soil (Lambe and Whitman, 1979). In terms of particle shape, both compressibility and compactibility are affected for a soil that
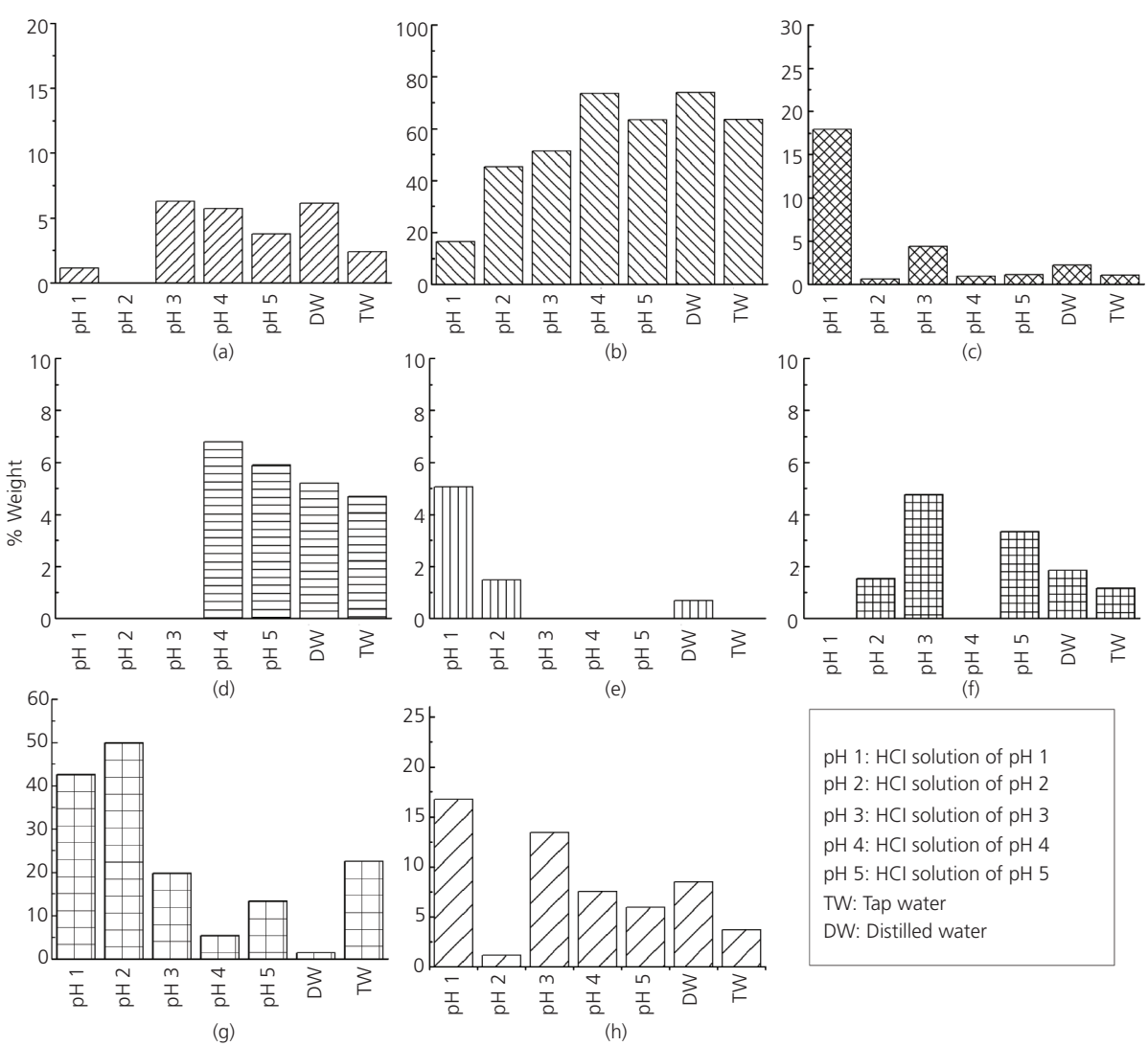

$\mathrm{pH}$ 1: $\mathrm{HCl}$ solution of $\mathrm{pH} 1$ $\mathrm{pH}$ 2: $\mathrm{HCl}$ solution of $\mathrm{pH} 2$ $\mathrm{pH}$ 3: $\mathrm{HCl}$ solution of $\mathrm{pH} 3$ $\mathrm{pH}$ 4: $\mathrm{HCl}$ solution of $\mathrm{pH} 4$ $\mathrm{pH}$ 5: $\mathrm{HCl}$ solution of $\mathrm{pH} 5$ TW: Tap water

DW: Distilled water

Figure 9. Measured percentage compositions of various elements retained on RMW samples after treatment with different solutions: (a) iron, (b) sodium, (c) silicon, (d) fluorine, (e) calcium, (f) copper, (g) chlorine, (h) aluminium 
Geotechnical Research

Volume 5 Issue GR2
Compaction and consolidation behaviour of untreated and treated waste of Indian

red mud

Reddy and Rao contains a mix of irregularly shaped particles, as they do not facilitate rearrangement of themselves as easily as would be the case for particles with spherical shapes (Toth et al., 1988). With this in mind, efforts are also devoted to establishing the particle shape, chemical constituents and surface charge properties of RMW and to scrutinise the likely influence of these factors on compaction and compressibility characteristics.

Figure 10 shows photomicrographs captured with the help of SEM, depicting the morphological characteristics of RMW. Also shown in the figure are major elemental compositions determined in the untreated RMW by the EDS technique. It can be observed from the images (Figure 10(a)) that the constituent particles of the waste are varied in sizes and are irregular in shape, highlighting that compaction and compressibility characteristics can be affected because of these irregularly shaped particles. Further, from the elemental compositions (Figure 10(b)), it can be observed that RMW is majorly constituted with iron (i.e. 49\%), followed by aluminium and sodium $(\mathrm{Na})$. As such, no detailed studies describing the influence of iron and aluminium contents on the compaction and compressibility characteristics of soils are available in the literature. However, the abundant availability of
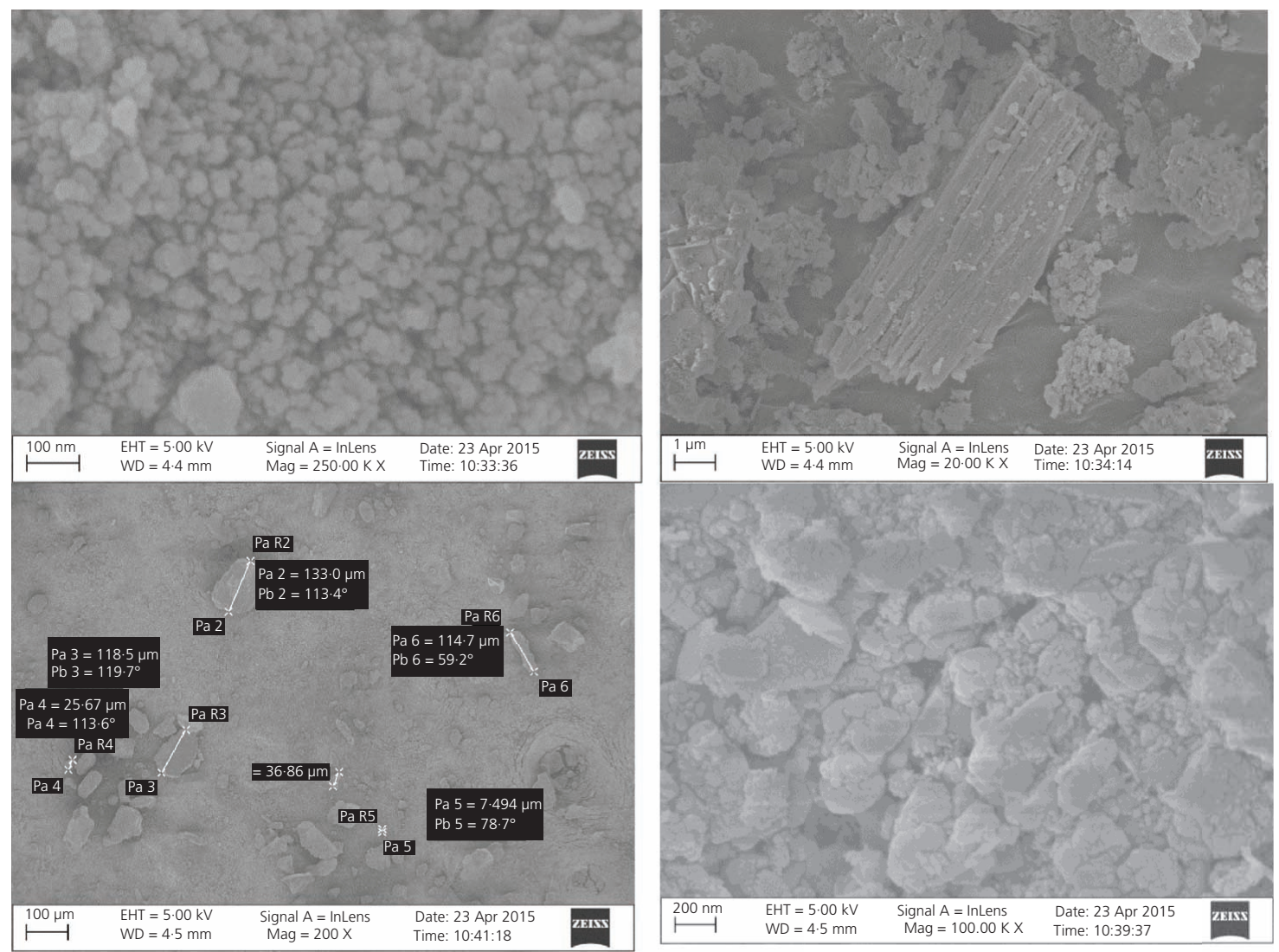

(a)

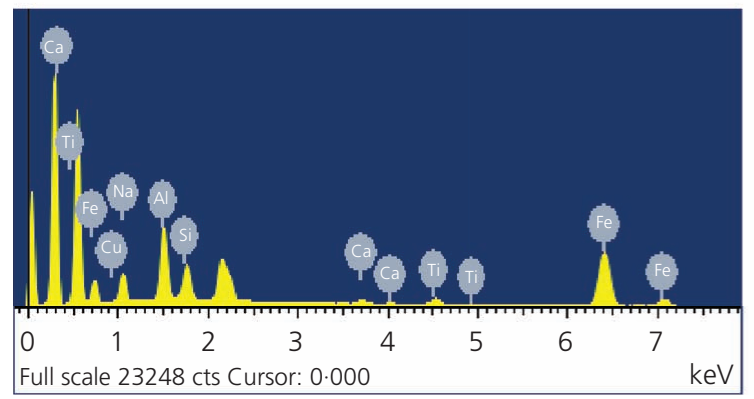

\begin{tabular}{|c|c|}
\hline Element & Weight: $\%$ \\
\hline Sodium & 13.53 \\
\hline Aluminium & 20.82 \\
\hline Silicon & 10.65 \\
\hline Calcium & 1.32 \\
\hline Titanium & 2.80 \\
\hline Iron & 49.36 \\
\hline Copper & 1.53 \\
\hline Total & 100.00 \\
\hline
\end{tabular}

(b)

Figure 10. (a) SEM images of RMW depicting irregularly shaped particles; (b) elemental analysis by EDS showing major elements in untreated RMW 
iron, aluminium and sodium can result in a considerable exchange of cations. causing flocculation and/or agglomerations simultaneously, which are believed to affect the compaction and compressibility characteristics of RMW.

Similarly, Figure 11 shows the variation in zeta potential, which gives a clear insight into the surface charge properties that can help in delineating the flocculation or dispersion characteristics of particles with $\mathrm{pH}$. It is evident from the results that the RMW particles possess surface charge characteristics. The measured zeta potential is positive up to a $\mathrm{pH}$ of 6.6 and turns to negative when the $\mathrm{pH}$ exceeds this value. As such, the positive and negative values can be interpreted as causing the flocculation or dispersion among the particles. This transformation from a flocculated to a dispersed structure with a change in $\mathrm{pH}$ had an effect on the compaction and compressibility characteristics of RMW, as shown in Figures 1, 2 and 5. Further, it is important to note that the dominance of hydrogen or hydroxyl ions on the surfaces of the particles is responsible for the positive or negative values of the zeta potential. As stated earlier, in the presence of hydrogen and aluminium ions, it is those aluminium ions that control the behaviour of a material, including its compaction and compressibility.

\section{Effect of treatment on $\mathrm{pH}$ reduction}

As highlighted earlier, one of the drawbacks in the effective utilisation of RMW is its high $\mathrm{pH}$. Hence, there is a necessity to bring down the $\mathrm{pH}$ to an acceptable level that has been specified by various codes or standards. Moreover, the chemicals being employed for treating the waste, apart from improving the density characteristics, should also prove to be effective in lowering the $\mathrm{pH}$ of the resultant mix. To verify this fact as well as to evaluate the efficacy of chemicals such as sodium chloride and hydrochloric acid used in the study, neutrality levels in terms of $\mathrm{pH}$ were measured, following the guidelines provided by the ASTM D 4972 standard (ASTM, 2013), on resultant samples

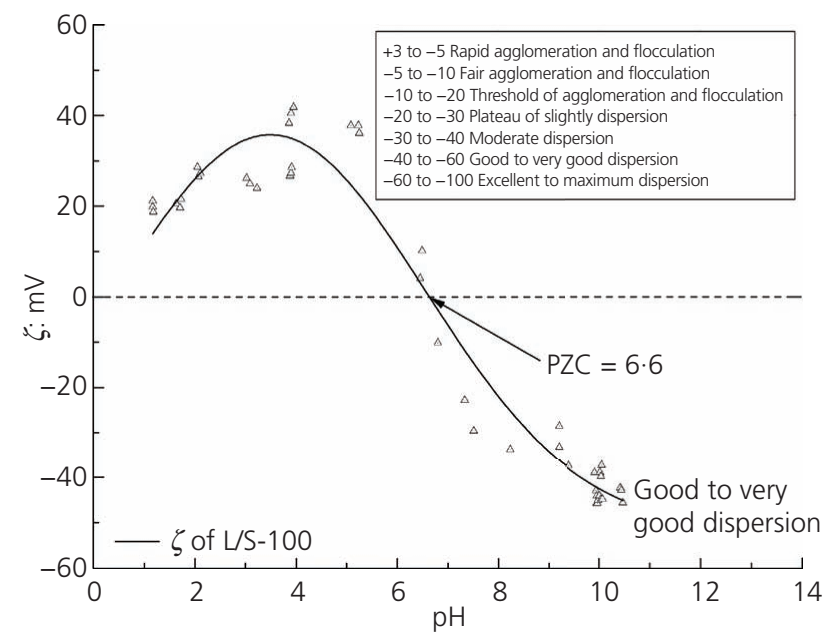

Figure 11. Variation in zeta potential with $\mathrm{pH}$ for untreated RMW. PZC, point of zero charge
Table 6. The values of measured $\mathrm{pH}$ on samples of postcompaction and consolidation tests

\begin{tabular}{lcc} 
& \multicolumn{2}{c}{ pH } \\
\cline { 2 - 3 } Sample & Post-compaction & Post-consolidation \\
\hline Untreated RM & 11.33 & 11.10 \\
pH 1 solution & 6.33 & 7.99 \\
pH 1.5 solution & 8.75 & 9.92 \\
pH 2 solution & 9.35 & 10.34 \\
pH 3 solution & 10.6 & 10.62 \\
pH 4 solution & 10.8 & Not conducted \\
3.42 M sodium & 9.49 & Not conducted \\
chloride solution & & \\
1.71 M sodium & 9.14 & Not conducted \\
chloride solution & &
\end{tabular}

obtained after post-compaction and post-consolidation tests. All the $\mathrm{pH}$ measurements have been carried out maintaining a liquidto-solid ratio of 1:1, and the results obtained are listed in Table 6 . From the results, a drastic decrease in $\mathrm{pH}$ levels from as high as 11.33 to as low as 6.33 with a decrease in the $\mathrm{pH}$ of hydrochloric acid solution can be observed. As such, treatment with hydrochloric acid solution at $\mathrm{pH}$ of 1 or 1.5 showed superior performance in attaining the neutrality levels of the treated waste. Also, a reasonable decrease in $\mathrm{pH}$ levels from $11 \cdot 33$ to $9 \cdot 14$ can be observed for the treatment with sodium chloride, indicating its effectiveness in neutralising RMW. Thus, the results clearly highlight that RMW can be neutralised using either hydrochloric acid or sodium chloride solutions with suitable concentrations.

\section{Concluding remarks}

In the present study, the compaction and consolidation behaviour of untreated and sodium chloride- and hydrochloric acid-treated RMW was evaluated by conducting extensive experimental investigations. The following major conclusions are drawn based on the results of the study.

- Red mud, a highly alkaline solid waste, offers resistance to the applied compaction energy, particularly when the energy is equal to that of the SP test, yielding inconsistent dry unit weight and optimum water content values. However, this limitation is surmounted when higher compaction energy, equal to that of the MP test, was applied, and this has also produced reliable dry unit weight and optimum water content values.

- Samples treated with hydrochloric acid and sodium chloride solutions are observed to yield consistent values of dry unit weight, and the difference in the values of dry unit weight between these two treated samples is found to be insignificant.

- A critical evaluation of compaction behaviour of RMW reveals that its dry unit weight-water content relationships are analogous to those of industrial wastes and chemically treated soils.

- Both untreated and treated wastes exhibited relatively low compressibility characteristics, and the values of $c_{\mathrm{c}}$ and $m_{\mathrm{v}}$ are found to vary with change in the $\mathrm{pH}$ of the pore fluid. 
- Compaction and consolidation results highlight that the waste can be treated using hydrochloric acid or sodium chloride solutions. The performance of the acid treatment in lowering the $\mathrm{pH}$ of the admixed waste was found to be superior to that with sodium chloride treatment.

- Particle shape, particle size, surface charge properties and chemical and mineralogical constituents are the key factors found to affect the compaction and compressibility characteristics of RMW.

- The elemental analysis results show the presence of no harmful chemical compositions in RMW, after treating it with different chemical solutions, distilled water or tap water. Moreover, the results demonstrate that the use of tap water for compaction and consolidation purposes is beneficial. The results also further suggest avoidance of treating the waste at extremely low $\mathrm{pH}$ conditions $(<3)$.

- The observed low compressibility characteristics qualify the waste to be selected in structural fill applications. Moreover, the unit weight results that conform to MoRD (2014) as well as IS 1498-1970 (BIS, 2007) code specifications endorse that red mud can be used as a resource material in constructing rural roads and embankments. However, the waste must be confined with an appropriate natural soil acting as its cover.

- The results demonstrate that RMW, with or without treatment, can be placed and compacted in all practical purposes in a way similar to that done with conventional soils.

There have been continuous efforts by the research fraternity striving towards resourceful utilisation of several wastes, in view of the rapid depletion of suitable natural materials in many of civil engineering applications. In this context, the results reported by this study bear a significant importance.

\section{Acknowledgements}

The authors are highly thankful to the Science and Engineering Research Board - Department of Science and Technology, Government of India, for the financial support (Grant Number SB/FTP/ETA-0297/2013) given to carry out this research work. The help is greatly acknowledged by the authors.

\section{REFERENCES}

AASHTO (American Association of State Highway and Transportation Officials) (2012) T99: Standard method of test for moisture-density relation of soils. AASHTO, Washington, DC, USA.

Alainachi IH and Alobaidy GA (2010) The effects of Basra Gulf salt water on the Proctor compaction and CBR test results of soil samples at Baniyas city, Abu Dhabi, UAE. Electronic Journal of Geotechnical Engineering 15(A): 1-17.

Arulrajah A, Disfani MM, Suthagaran V and Bo MW (2013) Laboratory evaluation of the geotechnical characteristics of waste water biosolids in road embankments. Journal of Materials in Civil Engineering 25(11): 1682-1691.

Arulrajah A, Maghoolpilehrood F, Disfani MM and Horpibulsuk S (2014) Spent coffee grounds as a non-structural embankment fill material: engineering and environmental considerations. Journal of Cleaner Production 72: 181-186, https://doi.org/10.1016/j.jclepro.2014.03.010.
ASTM (2007) D 698-07: Standard test methods for laboratory compaction characteristic of soil using standard effort. ASTM International, West Conshohocken, PA, USA.

ASTM (2008) D 4943-08: Standard test methods for shrinkage factors of soils by the wax method. ASTM International, West Conshohocken, PA, USA.

ASTM (2010a) D 4318-10: Standard test methods for liquid limit, plastic limit and plasticity index of soils. ASTM International, West Conshohocken, PA, USA.

ASTM (2010b) D 422-63: Standard test method for particle-size analysis of soils. ASTM International, West Conshohocken, PA, USA.

ASTM (2011a) D 2487-11: Standard practice for classification of soils for engineering purposes (USCS). ASTM International, West Conshohocken, PA, USA.

ASTM (2011b) D 2435-11: Standard test methods for one-dimensional consolidation properties of soils using incremental loading. ASTM International, West Conshohocken, PA, USA.

ASTM (2012) D 1557-12: Standard test methods for laboratory compaction characteristics of soil using modified effort. ASTM International, West Conshohocken, PA, USA.

ASTM (2013) D 4972-13: Standard test methods for $\mathrm{pH}$ of soils. ASTM International, West Conshohocken, PA, USA.

ASTM (2014a) D 854: Standard test methods for specific gravity of soil solids by water pycnometer. ASTM International, West Conshohocken, PA, USA.

ASTM (2014b) D 1140-14: Standard test methods for determining the amount of material finer than $75-\mu \mathrm{m}$ (No. 200) sieve in soils by washing. ASTM International, West Conshohocken, PA, USA.

Azadi MRE (2008) The effects of Urmieh lake salt water on the proctor compaction and CBR test results of well graded gravel-sand mixed with clay (GSCW) soil samples. Electronic Journal of Geotechnical Engineering 13(Bundle C): 10-22.

Babu GLS and Jaladurgam MER (2014) Strength and deformation characteristics of fly ash mixed with randomly distributed plastic waste. Journal of Materials in Civil Engineering 26(12): 1-7.

Borra CR, Pontikes Y, Binnemans K and Gerven TV (2015) Leaching of rare earths from bauxite residue (red mud). Minerals Engineering 76: 20-27, https://doi.org/10.1016/j.mineng.2015.01.005.

BIS (Bureau of Indian Standards) (2007) IS 1498-1970: Classification and identification of soils for general engineering purposes. Bureau of Indian Standards, New Delhi, India.

BIS (1997) IS 12269-1987: Criteria for design of small embankment dams. Bureau of Indian Standards, New Delhi, India.

Di Maio C (1996) Exposure of bentonite to salt solution: osmotic and mechanical effects. Géotechnique 46(4): 695-707, https://doi.org/10. 1680/geot.1996.46.4.695.

Di Maio C and Fenelli GB (1994) Residual strength of kaolin and bentonite: the influence of their constituent pore fluid. Géotechnique 44(2): 217-226, https://doi.org/10.1680/geot.1994.44.2.217.

Edil TB, Sandstrom LK and Berthouex PM (1992) Interaction of inorganic leachate with compacted pozzolanic fly ash. Journal of Geotechnical Engineering 118(9): 1410-1430.

Ekrem K (2006) Utilization of red mud as a stabilization material for the preparation of clay liners. Engineering Geology 87(3-4): 220-229.

Giannopoulou I, Dimas D, Maragkos I and Panias D (2009) Utilization of metallurgical solid by-products for the development of inorganic polymeric construction materials. Global NEST Journal 11(2): 127-136.

Gray DH and Somogyi F (1974) Engineering Properties and Dewatering Characteristics of Red Mud Tailings. Alcoa Foundation, Pittsburgh, PA, USA, DRDA Project 340364, p. 100.

Hajela RB, Gupta RG and Goel RK (1989) Disposal of solid wastes-red mud and fly-ash in the production of heavy clay products. International Journal of Environmental Studies 33(1-2): 125-132. 
Hanahan C, McConchie D, Pohl J et al. (2004) Chemistry of sea water neutralization of bauxite refining residues (red mud). Environmental Engineering Science 21(2): 125-138.

Hanson JL, Yesiller N, Stockhausen SAV and Wong WW (2010) Compaction characteristics of municipal solid waste. Journal of Geotechnical and Geoenvironment Engineering 136(8): 1095-1102.

Havanagi VG, Sinha AK, Arora VK and Mathur S (2012) Waste materials for construction of road embankment and pavement layers. International Journal of Environmental Engineering Research 1(2): 51-59.

Holtz RD and Kovacs WD (1981) An Introduction to Geotechnical Engineering. Pearson, Englewood Cliffs, NJ, USA.

IRC (Indian Road Congress) (2001a) IRC SP 20-2001: Rural roads manual. IRC, New Delhi, India.

IRC (2001b) IRC SP 58-2001: Guidelines for use of fly ash in road embankment. IRC, New Delhi, India.

IRC (2007) IRC SP 72-2007: Guidelines for the design of flexible pavement for low volume rural roads. IRC, New Delhi, India.

Izquierdo M and Querol X (2012) Leaching behaviour of elements from coal combustion fly ash: an overview. International Journal of Coal Geology 94: 54-66, https://doi.org/10.1016/j.coal.2011.10.006.

Kaniraj SR and Havanagi VG (2001) Correlation analysis of laboratory compaction of fly ashes. Practice Periodical of Hazardous, Toxic, and Radioactive Waste Management 5(1): 25-32.

Kehagia F (2008) An innovative geotechnical application of bauxite residue. Electronic Journal of Geotechnical Engineering 13(G): 1-9.

Khaitan S, Dzombak DA and Lowry GV (2009a) Mechanisms of neutralization of bauxite residue by carbon dioxide. Journal of Environmental Engineering 135(6): 433-438, https://doi.org/10.1061/ (ASCE)EE.1943-7870.0000010.

Khaitan S, Dzombak D and Lowry GV (2009b) Chemistry of the acid neutralization capacity of bauxite residue. Environmental Engineering Sciences 26(5): 873-881.

Khaitan S, Dzombak DA, Swallow P et al. (2010) Field evaluation of bauxite residue neutralization by carbon dioxide, vegetation, and organic amendments. Journal of Environmental Engineering 136(10): 1045-1053.

Lambe TW (1960) Compacted clay: structure. Transactions of the American Society of Civil Engineers 125(1): 681-705.

Lambe TW and Whitman RV (1979) Soil Mechanics. Wiley, New York, NY, USA.

Leroueil S (1988) Tenth Canadian Geotechnical Colloquium: recent developments in consolidation of natural clays. Canadian Geotechnical Journal 25(1): 85-107.

Li LY (1998) Properties of red mud tailings produced under varying process conditions. Journal of Environmental Engineering 124(3): 254-264.

Liu CN, Chen RH and Chen KS (2006) Unsaturated consolidation theory for the prediction of long term municipal solid waste landfill settlement. Waste Management and Research 24(1): 80-91.

Madhyannapu RS, Madhav MR, Puppala AJ and Ghosh A (2008) Compressibility and collapsibility characteristics of sedimented fly ash beds. Journal of Materials in Civil Engineering 20(6): 401-409.

Mansour ZM, Taha MR and Chik Z (2008) Fresh-brine water effect on the basic engineering properties of Lisan Marl-Dead Sea-Jordan. Journal of Applied Sciences 8(20): 3603-3611.

McLaren RJ and Digioi AM (1987) The typical engineering properties of fly ash. In Geotechnical Practice for Waste Disposal '87 (Woods R (ed.)). American Society of Civil Engineers, New York, NY, USA, vol. 13 , pp. 683-697.

Ministry of Railways (2006) Study Report on Use of Coal Ash in Railway Embankment. Ministry of Railways, New Delhi, India, GE 0-S005, p. 39.

Mitchell JK (1976) Fundamentals of Soil Behaviour. Wiley, New York, NY, USA.

Mohammadinia A, Arulrajah A, Sanjayan J et al. (2015) Geotechnical properties of lightly stabilized recycled demolition materials in base/ sub-base applications. IFCEE 2015 (Iskander M, Suleiman MT, Anderson JB and Laefer DF (eds)). American Society of Civil Engineers, Reston, VA, USA, pp. 2767-2776.

MoRD (Ministry of Rural Development) (2014) Specifications for Rural Roads, 1st Revision. MoRD, Government of India, New Delhi, India.

MoRTH (Ministry of Road Transport and Highways) (2000) Specifications for Road and Bridge Works, 3rd Revision. IRC, New Delhi, India.

Newson T, Dyer T, Adam C and Sharp S (2006) Effect of structure on the geotechnical properties of bauxite residue. Journal of Geotechnical and Geoenvironment Engineering 123(2): 143-151.

Nikraz HR, Bodley AJ, Cooling DJ, Kong PYL and Soomro M (2007) Comparison of physical properties between treated and untreated bauxite residue mud. Journal of Materials in Civil Engineering 19(1): $2-9$.

Paaswell RE (1967) Temperature effects on clay soil consolidation. Journal of the Soil Mechanics and Foundations Division 93(3): 9-22.

Pal SK and Ghosh A (2014) Volume change behavior of fly ash-montmorillonite. International Journal of Geomechanics 14(1) 59-68.

Parekh BK and Goldberger WM (1976) An Assessment of Technology for Possible Utilization of Bayer Process Muds. US Environmental Protection Agency, Washington, DC, USA, EPA/600/2-76/301, p. 154.

Power G, Gräfe M and Klauber C (2011) Bauxite residue issues: I. current management, disposal and storage practices. Hydrometallurgy 108(1-2): 33-45.

Rai S, Wasewar KL, Mukhopadhyay J, Yoo CK and Uslu H (2012) Neutralization and utilization of red mud for its better waste management. Archives of Environmental Science 6: 13-33.

Rai S, Wasewar KL, Lataye DH, Mukhopadhyay J and Yoo CK (2013) Feasibility of red mud neutralization with seawater using Taguchi's methodology. International Journal of Environmental Science and Technology 10(2): 305-314.

Raza SA, Khan MA and Ahmad MS (1999) Consolidation behavior of treated and reinforced fly ash. Proceedings of Fly Ash Disposal and Deposition: Beyond 2000 AD, Kanpur, India, pp. 216-222.

Reddy NG and Rao BH (2016) Evaluation of the compaction characteristics of untreated and treated red mud. In Geo-Chicago 2016: Sustainable Materials and Resource Conservation (Reddy KR, Yesiller N, Zekkos D, Farid A and De A (eds)). American Society of Civil Engineers, Reston, VA, USA, GSP 272, pp. 23-32.

Reddy KR, Hettiarachchi H, Parakalla NS, Gangathulasi J and Bogner JE (2009) Geotechnical properties of fresh municipal solid waste at Orchard Hills Landfill, USA. Waste Management 29(2): 952-959, https://doi.org/10.1016/j.wasman.2008.05.011.

Rout SK, Sahoo T and Das SK (2013) Design of tailing dam using red mud. Central European Journal of Engineering 3(2): 316-328.

Rubinos D, Spagnoli G and Barral MT (2015) Assessment of bauxite refining residue (red mud) as a liner for waste disposal facilities. International Journal of Mining, Reclamation and Environment 29(6): 433-452.

Rujikiatkamjorn C, Indraratna B, Chiaro G, Naeeni S and Tasalloti SMA (2012) Compaction and strength testing of industrial waste blends as potential port reclamation fill. In 11th Australia-New Zealand Conference on Geomechanics: Ground Engineering in a Changing World (Narsilio GA, Arulrajah A and Kodikara J (eds)). Engineers Australia, Melbourne, Australia, pp. 973-978.

Sinha UN, Karthigeyan S, Bhargava SN and Sharma AK (1998) Compressibility characteristics of pond ash used as geomaterial. Indian Geotechnical Journal 28(4): 377-387.

Sinha AK, Havanagi VG, Ranjan A, Mathur S and Singh BK (2013) Geotechnical characterization of jarosite waste material for road construction. Proceedings of Indian Geotechnical Conference, Roorkee, India, pp. 1-4. 
Geotechnical Research

Volume 5 Issue GR2
Compaction and consolidation behaviour of untreated and treated waste of Indian red mud

Reddy and Rao
Sivapullaiah PV and Reddy PHP (2009) Fly ash to control alkali-induced volume changes in soils. Proceedings of the Institution of Civil Engineers - Ground Improvement 162(4): 167-173.

Skempton AW (1953) The colloidal activity of clays. Proceedings of the 3rd International Conference on Soil Mechanics and Foundation Engineering, London, UK, vol. 1, pp. 57-61.

Somogyi F and Gray DH (1977) Engineering properties affecting disposal of red mud. Proceedings of the Conference on Geotechnical Practice for Disposal of Solid Waste Materials, Ann Arbor, MI, USA, pp. 1-22.

Sowers GF (1973) Settlement of waste disposal fills. Proceedings of the 8th International Conference on Soil Mechanics and Foundation Engineering, Moscow, Russia, vol. 4, pp. 207-210.

Sridharan A and Sivapullaiah PV (2005) Mini compaction test apparatus for fine grained soils. Geotechnical Testing Journal 28(3): 1-7.

Srivastava RK (1997) Geotechnical aspects of soil-industrial waste interaction behavior. Proceedings of the International Symposium on Engineering Geology and the Environment, Athens, Greece, vol. 2, pp. $23-27$.
Sundaram R and Gupta S (2010) Construction of foundation on red mud. Proceedings of the 6th International Congress on Environmental Geotechnics, New Delhi, India, pp. 1172-1175.

Terzaghi K, Peck RB and Mesri G (1996) Soil Mechanics in Engineering Practice. Wiley, New York, NY, USA.

Toth, PS, Chan HT and Cragg CB (1988) Coal ash as structural fill, with special reference to Ontario experience. Canadian Geotechnical Journal 25(4): 644-704.

Tu W, Zand B, Ajlouni MA, Butalia TS and Wolfe WE (2007) The consolidation characteristics of impound class $\mathrm{F}$ fly ash - a case history. Proceedings of the World of Coal Ash (WOCA - 2007), Covington, Northern Kentucky, USA, pp. 1-14.

Vipulanandan C and Mohammed A (2016) XRD and TGA, swelling and compacted properties of polymer treated sulfate contaminated CL soil. Journal of Testing and Evaluation 44(6): 2270-2284.

Winterkorn HF and Fang HY (1991) Soil technology and engineering properties of soils. In Foundation Engineering Handbook (Fang FY (ed.)). Springer, New York, NY, USA, pp. 88-143.

\section{How can you contribute?}

To discuss this paper, please submit up to 500 words to the editor at journals@ice.org.uk. Your contribution will be forwarded to the author(s) for a reply and, if considered appropriate by the editorial board, it will be published as a discussion in a future issue of the journal. 